\title{
Tinjauan PSAK 102 Penerapan Akuntansi Murabahah Dalam Pembiayaan Kredit Kepemilikan Rumah
}

\author{
Agus Taufik Hidayat, Nurhayati \\ STIE PGRI Dewantara Jombang
}

Korespondensi: agustaufikhidayat7799@gmail.com

\begin{abstract}
abstrak
Penelitian ini bertujuan untuk mengetahui kesesuaian penerapan akuntansi pembiayaan murabahah pada Bank BRI Syariah, terhadap Pernyataan Standar Akuntansi Keuangan Nomor 102 tentang Akuntansi Murabahah. Penelitian ini berjenis kualitatif. Data yang digunakan adalah data primer yang diperoleh melalui wawancara, dan dokumentasi. Hasil analisis menunjukan bahwa pembiayaan Kredit Kepemilikan Rumah (KPR) pada Bank BRI Syariah tidak sesuai dengan Pernyataan Standar Akuntansi Keuangan Nomor (PSAK) 102 tentang Akuntansi Murabahah. Dalam unsur pengakuan dan pengukuran ada beberapa item yang tidak sesuai dengan PSAK 102 yaitu, dalam angsuran penerimaan denda Bank BRI Syariah mengakui denda sebagai pendapatan hal itu tidak sesuai dengan PSAK 102. Di dalam pelaksanaan pembiayaan murabahah, Bank BRISyariah Cabang Jombang bertindak sebagai penjual dan nasabah sebagai pembeli. Selain itu, terdapat perbedaan antara bunga bank konvensional dan bank syariah yaitu bank konvensional menetukan bunga dibuat pada waktu akad dengan asumsi harus selalu untung, sedangkan bank syariah penentuan besarnya rasio/bagi hasil dibuat waktu akad dengan berpedoman pada kemungkinan untung rugi.
\end{abstract}

Kata kunci : Akuntansi murabahah. Bank BRISyariah. Pernyataan Standar Akuntansi Keuangan Nomor 102.

\begin{abstract}
This study aims to determine the suitability of the application of murabahah financing accounting to the BRISyariah Bank, to the Statement of Financial Accounting Standards Number 102 concerning Murabahah Accounting. The kind of research is qualitative. The data collection techniques used are interview techniques and documentation. The results of the analysis show that the financing of Home Ownership Credit (KPR) at Bank BRI Syariah is not in accordance with the Statement of Financial Accounting Standards Number (PSAK) 102 concerning Murabahah Accounting. The element of recognition and measurement there are several items that are not in accordance with PSAK 102 that is, in installments the receipt of fines Bank BRI Syariah recognizes fines as income that is not in accordance with PSAK 102. In the implementation of murabahah financing, Bank BRI Syariah Branch Jombang acts as a seller and customer as a buyer. In addition, there is a difference between the interest of conventional banks and Islamic banks, namely conventional banks determine that interest is made at the time of the contract with the assumption that it must always be profitable, while Islamic banks determine the ratio / profit sharing made by contract time based on the possibility of profit and loss.
\end{abstract}

Keywords : Murabahah accounting, BRI Syariah Bank, Statement of Financial Accounting Standards Number 102.

\section{A. LATAR BELAKANG}

Sebagai salah satu perusahaan perbankan ternama di Indonesia, Bank Rakyat Indonesia (BRI) Syariah perlu untuk menunjukkan eksistensinya di masyarakat melalui berbagai produk dan kegiatannya antara lain melalui berbagai program/produk yang menarik bagi konsumen serta masyarakat luas melalui program corporate social responsibility (CSR) yang merupakan keharusan bagi perusahaan, sebagai salah satu bentuk nyata pembangunan ekonomi di masyarakat (Purbowati, R., \& Mutiarni, R. 2017) pada agar dap Bank syariah memiliki sistem operasional yang berbeda dengan bank konvensional. Dalam bank syariah memberikan layanan bebas bunga kepada para nasabahnya. Dalam sistem operasional bank syariah, penarikan bunga dilarang dalam semua bentuk transaksi apapun. Bank syariah tidak mengenal yang namanya sistem 
bunga, baik itu bunga yang diperoleh dari nasabah yang meminjam uang atau bunga yang dibayar kepada penyimpan dana di bank syariah. Bank pada dasarnya fungsi utama Bank Syariah tidak jauh beda dengan bank konvensional yaitu menghimpun dana dari masyarakat kemudian menyalurkannya kembali atau lebih dikenal sebagai fungsi intermediasi. Dalam prakteknya bank syariah menyalurkan dana yang diperolehnya dalam bentuk pemberian pembiayaan, baik itu pembiayaan modal usaha maupun untuk komsumsi. Dalam praktiknya, bagi lembaga keuangan syariah, maka penerapan prinsipprinsip akuntansi Syariah juga perlu dilakukan (Anisah, N., \& Utomo, L. P, 2017).

Pembiayaan merupakan aktivitas bank syariah dalam menyalurkan dana kepihak lain selain bank bank berdasarkan prinsip bank. Penyaluran dana dalam bentuk pembiayaan didasarkan pada kepercayaan yang diberikan oleh pemilik dana kepada pengguna dana. Pemilik dana percaya kepada penerima dana, bahwa dana dalam bentuk pembiayaan yang diberikan pasti terbayar. Penerima pembiayaan mendapat kepercayaan diri dari pemberi pembiayaan, sehingga penerima pembiayaan berkewajiban untuk mengembalikan pembiayaan yang diterimanya sesuai jangka waktu yang telah diperjanjikan dalam akad pembiayaan. Adapun pengertian pembiayaan menurut berbagai litertur yang ada sebagai berikut, Menurut Undang-Undang No.10 Tahun 1998 Pembiayaan adalah penyediaan uang atau tagihan yang dapat dipersamakan dengan itu, berdasarkan persetujuan atau kesepakatan antara bank dengan pihak lain yang mewajibkan pihak yang dibiayai untuk mengembalikan uang atau tagihan tersebut setelah jangka waktu tertentu dengan imbalan atau bagi hasil.

Menurut Alfiatus (2015: 165),"Pembiayaan adalah aktivitas menyalurkan dana yang terkumpul kepada anggota pengguna dana, memilih jenis usaha yang akan dibiayai agar diperoleh jenis usaha yang produktif, menguntungkan dan dikelola oleh anggota yang jujur dan bertanggung jawab". Berdasarkan pengertian tersebut diatas, dapat disimpulkan bahwa pembiayaan adalah pemberian fasilitas penyediaan dana untuk mendukung investasi yang telah direncanakan berdasarkan kesepakatan antara bank dengan pihak lain yang mewajibkan pihak yang dibiayai untuk mengembalikan uang atau tagihan tersebut setelah jangka waktu tertentu dengan imbalan atau bagi hasil. Dalam aplikasi bank syariah, bank merupakan penjual atas objek barang dan nasabah merupakan pembeli. Bank menyediakan barang yang dibutuhkan oleh nasabah dengan membeli barang dari supplier, kemudian menjualnya kepada nasabah dengan harga yang lebih tinggi dibandingkan harga beliyang dilakukan oleh bank syariah.

Bank syariah dapat memberikan pembiayaan murabahah untuk pembelian barang (aset) yang telah tersedia, misalnya pembiayaan untuk pembelian rumah oleh nasabah. Dalam produk pembiayaanMurabahah yang telah dikembangkan oleh bank syariah adalah pembiayaan rumah, atau yang sering dikenal dengan istilah KPR syariah. Kebanyakan orang dikalangan menengah untuk memiliki sebuah rumah jika membelinya dengan cara tunai dirasa kurang mampu, oleh karena itu bank syariah memberikan pembiayaan yang dibayar dengan diangsur, jumlah angsuran yang telah ditetapkan diawal dan merupakan angsuran yang dibayar di muka dan dibayar setiap bulan. Harga jual biasanya sudah ditambah dengan margin keuntungan yang disepakati antara bank syariah dan pembeli. Margin keuntungan merupakan selisih antara harga jual dan harga beli bank syariah. Margin keuntungan akan diakui oleh bank syariah pada periode terjadinya, apabila akad berakhir pada periode yang sama. Bila jangka waktu murabahah melebihi satu periode, maka margin keuntungan atas jual beli dalam pembiayaan murabahah akan diakui sebagai keuntungan proposional, dimana keuntungan diakui dengan mengalikan presentase keuntungan terhadap jumlah piutang yang jatuh tempo pada periode yang bersangkutan. 
Harga jual rumah ditetapkan di awal ketika nasabah menandatangani perjanjian pembiayaan jual beli rumah, dengan angsuran tetap hingga jatuh tempo pembiayaan.Dalam pembiayaan akad murabahah nasabah juga diuntungkan ketika ingin melunasi angsuran sebelum masa kontrak berakhir, karena bank syariah tidak akan mengenakan pinalti. Bank syariah tidak memberlakukan sistem pinalti karena harga KPR sudah ditetapkan sejak awal( Sugiawati: 2009). Dalam PSAK 102 dijelaskan bahwa pembiayaan murabahah dapat dilakukan dengan pesanan atau tanpa pesanan, dalam artian bahwa bank syariah lah yang menyediakan barang sesuai pesanan pembeli atau melakukan pembelian barang sekalipun ada pembeli atau tidak, sehingga perlakuan akuntansi terhadap transaksi pembiayaan murabahah tersebut telah diatur mengenai pengakuan dan pengukuran, penyajian dan pengungkapannya (Sulistyo: 20016)

Dalam perjanjian transaksi yang dimiliki dari akad ini mempengaruhi perlakuan akuntansinya masing-masing. Mulai dari pengakuan, pengukuran, pencatatan, dan pelaporannya. Standar akuntansi 102 tentang akuntansi Murabahah (jual- beli) menjadi acuan dari penerapan perlakuan akuntansi menggunakan akad Murabahah (jual-beli). Didalam standar akuntansi sudah diterangkan mengenai berbagai transaksi yang harus diakui sepertipada saat penerimaan uang muka nasabah untuk akad Murabahah (jual-beli), pengukuran aset yang diperoleh, pengukuran piutang dan dendanya, pencatatan tiap transaksinya, penyajian laporannya, dan pengungkapan lainnya.

Sebagai acuan dari penelitian ini dikemukakan hasil-hasil yang telah dilaksanakan sebelumnya, antara lain; Ulya Khalid (2009), Evaluasi Transaksi Murabahah berdasarkan Fikih Muamalah dan PSAK 102 (akuntansi murabahah) Studi Kasus PT Bank Pembiayaan Rakyat Syariah Harta Insan Karimah Cabang Ciledug. Dari hasil penelitian bahwa terdapat ketidaksesuaian pada penerapan akuntansi dan transaksi murabahah didasarkan dari PSAK No. 102 (Akuntansi Murabahah) terdiri dari karakteristik, pengakuan, pengukuran, penyajian, dan pengungkapan. dan fikih muamalah di BPRS HIK Cabang Ciledug. Siswadi Sululing (2014), tentang Penerapan Akuntansi Murabahah Terhadap Pembiayaan Kredit Kepemilikan Rumah(KPR)Pada Bank BRISyariah Cabang Jombang. Dari hasil penelitian disimpulkan pembiayaan Kredit Kepemilikan Rumah (KPR) pada Bank BRISyariah Cabang Jombang telah sesuai dengan Pernyataan Standar Akuntansi Keuangan Nomor 102 tentang Akuntansi Murabahah. Di dalam pelaksanaan pembiayaan murabahah, Bank BRISyariah Cabang Jombang bertindak sebagai penjual dan nasabah sebagai pembeli. Selain itu, terdapat perbedaan antara bunga bank konvensional dan bank syariah yaitu bank konvensional menetukan bunga dibuat pada aktuakad dengan asumsi harus selalu untung, sedangkan bank syariah penentuan besarnya rasio/bagi hasil dibuat waktu akad dengan berpedoman pada kemungkinan untung rugi.

Bank BRI Syariah merupakan bank syariah yang memberikan pembiayaan dalam produk murabahah. Produkmurabahah merupakan produk pembiayaan yang paling banyak digunakan dalam kegiatan pembiayaannya. Syarat dalam pemberian akad pembiayaan murabahahmerupakan hal utama untuk memberikan pembiayaan. Peneliti ingin mengetahui bagaimana syarat pembiayaan murabahah yang akan diberikan pada nasabah yang akan menggunakan pembiayaan tersebut.

Penerapan Akuntansi Pembiayaan murabahah dalam pembiayaan KPR dalam perlakuan akuntansi perlu digunakan suatu standart supaya proses akuntansi bisa benar, relevan, dipercaya, dipahami, serta dapat dibandingkan. Untuk itu peneliti ingin mengetahuai penerapan akuntansi dalam pembiayaan KPR berdasarkan PSAK 102 yang didalamnya diukur dengan cara sesuai pengakuan dan pengukuran, penyajian serta pengungkapan. 


\section{B. KAJIAN PUSTAKA \\ 1. Pengertian Pembiayaan}

Pembiayaan pada masyarakat pada saat sekarang ini sangat diperlukan. Survei Biro Pusat Statistik (BPS) menunjukkan data bahwa kendala yang dihadapi usaha kecil di 20 propinsi adalah masalah modal yaitu sebesar $31 \%$, bahan baku $26 \%$, pemasaran $21 \%$, kompetisi $17 \%$, teknik produksi $2 \%$, dan manajemen 2\%, Sunaryo (2008:3).Hal ini menunjukkan bahwa pada dataran ekonomi produktif, permasalahan modal atau biaya masih menjadi hal yang utama sehingga pembiayaan dari luar pengelola/pemilik unit produktif mutlak diperlukan. Menurut Peraturan Bank Indonesia Nomor: 9/19/PBI/2007 tentang Pelaksanaan Prinsip Syariah dalam Kegiatan Penghimpunan Dana dan Penyaluran Dana serta Pelayanan Jasa Bank Syariah, Ditetapkan pada tanggal 17 Desember 2007, definisi pembiayaan adalah penyediaan dana atau tagihan/piutang yang dapat dipersamanakan dengan itu. Sedangkan menurut Undang-undang Nomor 21 Tahun 2008 tentang Perbankan Syariah definisi pembiayaan adalah penyediaan dana atau tagihan yang dipersamakan dengan itu (Sayyid:2006). Berdasarkan Pasal 1 angka 12 Undang-undang Nomor 10 Tahun 1998 tentang Perubahan Atas Undang-undang Nomor 7 Tahun 1992 tentang Perbankan, pembiayaan berdasarkan prinsip syariah adalah penyediaan uang atau tagihan yang dipersamakan dengan itu berdasarkan persetujuan atau kesepakatan antara bank dengan pihak lain yang mewajibkan pihak yang dibiayai untuk mengembalikan uang atau tagihan tersebut setelah jangka waktu tertentu dengan imbalan atau bagi hasil. Jadi dapat disimpulkan bahwa pembiayaan adalah salah satu jenis dan kegiatan usaha lembaga keuangan syariah untuk menyediakan dananya atau tagihannya kepada masyarakat/nasabah dengan kewajiban masyarakat mengembalikan dana atau tagihan tersebut setelah jangka waktu tertentu dengan imbalan (margin) atau bagi hasil.

\section{Pembiayaan Murabahah}

Murabahah adalah akad jual beli atas barang tertetu, dimana penjual menyebutkan harga pembelian barang kepada pembeli kemudian menjual kepada pihak pembeli dengan mensyaratkan keuntungan yang diharapkan. Sesuai jumlah tertentu. Dalam akad murabahah, penjual menjual barangnya dengan meminta kelenihan atas harga beli dengan harga jual. Perbedaan antara harga jual dan harga beli barang disebut dengan margin keuntungan, Masyhuri \& Zainuddin (2008:138).

\section{Perlakuan Terhadap Unsur PSAK 102}

Ruang lingkup PSAK ini adalah untuk lembaga keuangan syariah dan koprasi syariah yang melakukan transaksi murabahah baik sebagai penjual maupun pembeli serta pihak lain yang melakukan transaksi murabahah dengan entitas-entitas tersebut. Standar akuntansi tentang jual beli murabahah mengacu pada PSAK 102 tentang Akuntansi Murabahah yang mulai berlaku efektif sejak 1 Januari 2008. PSAK ini menggantikan PSAK 59. PSAK 102 bertujuan untuk mengatur pengakuan, pengukuran, penyajian dan pengungkapan transaksi murabahah. Disamping itu, PSAK 102 juga diterapkan oleh pihak-pihak yang melakukan transaksi murabahah dengan lembaga keuangan tersebut (Muhammad, 2005) 


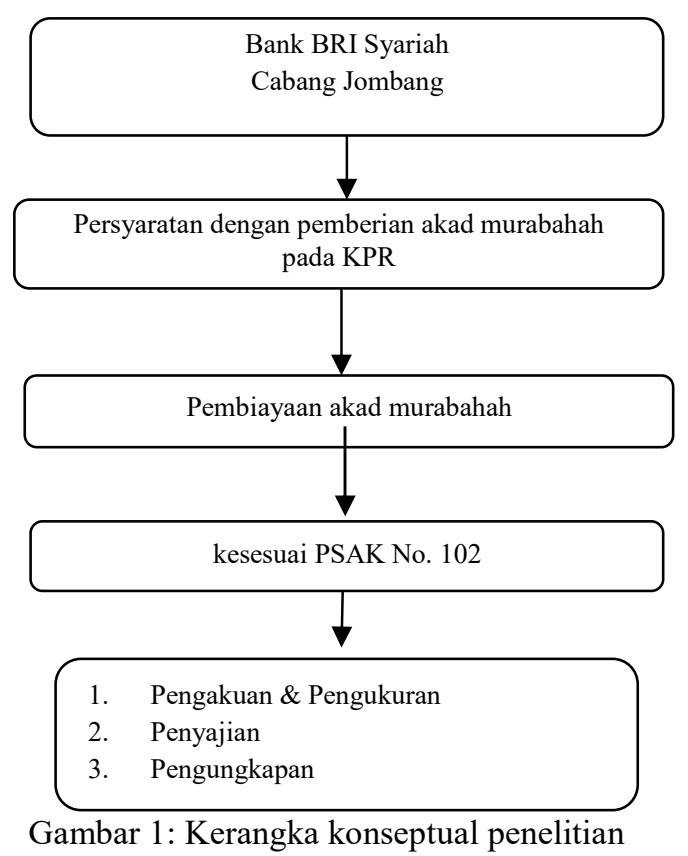

\section{METODE PENELITIAN}

Penelitian ini bersiat deskriptif kualitatif dengan pendekatan studi kasus, yang dilakukan dengan cara pengamatan langsung atau observasi, wawancara, dan dokumentasi metode penelitian deskriptif jenis studi kasus, Lokasi penelitian ini adalah PT. Bank BRI Syariah Cabang Jombang yang beralamatkan di Jl. KH. Wahid Hasyim No.9 A / 1-2 Jombang.

\section{Metode Pengumpulan Data}

Metode pengumpulan data adalah cara-cara yang dapat digunakan oleh peneliti untuk mengumpulkan data dimana cara-cara tersebut menunjuk pada sesuatu yang abstrak, tidak dapat diwujudkan dalam benda yang kasat mata, tetapi hanya dapat dipertontonkan penggunaannya (Nur hayati 2014: 60).

Metode pengumpulan data yang digunakan dalam penelitian ini adalah dengan metode wawancara kepada pegawai bagian legal pembiayaan dan bagian accounting yang berada di PT. Bank BRI Syariah Cabang Jombang. Selain itu, peneliti juga melengkapidengan data yang berupa dokumentasi laporan keuangan dari BSI Syariah.

\section{Teknik Analisis Data}

Dalam penelitian ini, penulis menggunakan metode analisis data Deskriptif-Kualitatif.

Menurut Milei dan Huberman (1984) dalam Novan (2011: 129) ada tiga macam kegiatan dalam analisis data kualitatif, yaitu :

1. Reduksi data, menujuk pada proses pemilihan, pemfokusan, penyederhanaan, abstraksi, dan pentransormasian "data mentah" yang terjadi dalam catatan-catatan lapangan tertulis.

2. Metode data (Data Display). Bentuk yang paling sering dari model kualitatif selama ini adalah teks naratif dan untuk menjadi yakin penulis memilih model yang lebih baik dalam tujuan pekerjaan. Metode tersebut tercakup berbagai jenis matrik, grafik, jaringan kerja, dan bagan.

3. Penarikan atau Verifikasi kesimpulan

Dari uraian diatas, maka secara sistematis analisa dan Deskripti kualitatif yang digunakan dalam penelitian ini adalah :

1. Pengumpulan data, baik data primer maupun sekunder yang diperoleh dari studi kepustakaan dan studi lapangan tentang akuntansi pembiayaan murabahah.

2. Menyajikan data secara diskriptif kemudian dianalisis dan disesuaikan antara konsep 
dan pelaksanakan penerapan akuntansi murabahah dalam pembiayaan KPR pada PT. Bank BRI Syariah Cabang Jombang berdasarka PSAK 102.

3. Melakukan pengulasan kembali dengan membuat tabel perbandingan antara konsep ideal yang ada dengan realitanya sehingga diperoleh hasil yang mudah dibaca.

4. Penarikan kesimpulan secara diskriptif veriikasi mendeskripsikan hasil yang diperoleh yang merupakan hasil akhir penelitian secara keseluruhan.

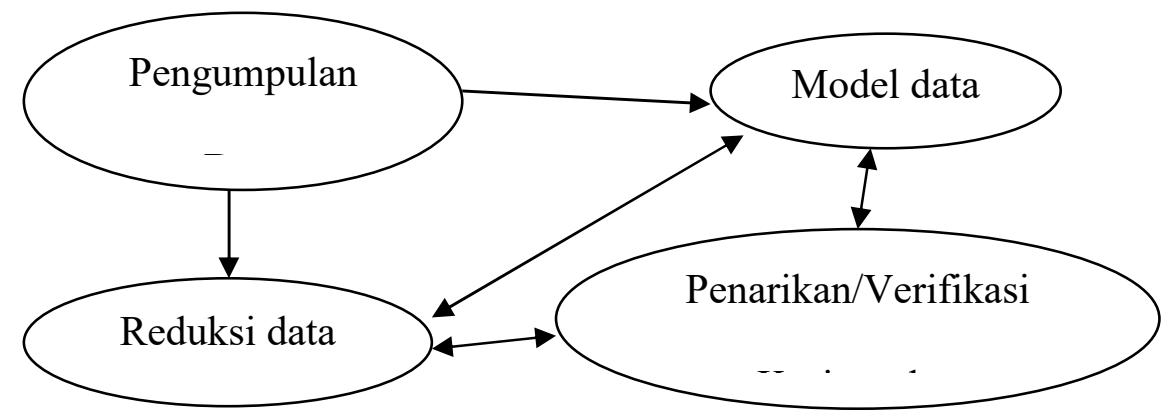

D. HASIL PENELITIAN

Gambar 2 Komponen Analisis Data: Model Interaktif

1. Penerapan Akuntansi Murabahah terhadap BRISyariah Cabang Jombang (PSAK 102)

Dalam pembiayaan KPR pada Bank BRISyariah Cabang Jombang, keuntungan disebut margin yang merupakan pendapatan bank, dimana besarnya margin telah ditetapkan oleh Bank BRISyariah tersebut. Plafon pembiayaan di BRISyariah minimal Rp. 25.000.000,- dan Maksimal Rp.3.000.000.000,- , dan cicilan tetap perbulannya. Dan tenor atau jangka waktu fleksibel maksimal 15 tahun. Dalam hal tersebut bank BRISyariah juga memperbolehkan pinalti yang akan nasabah bayar sebelum waktu pelunasan telah berakhir.

\section{Pengakuan dan Pengukuran Menurut BRISyariah}

Pada saat perolehan, aset murabahah diakui sebagai persediaan sebesar biaya perolehan.Murabahah dapat dilakukan berdasarkan pesanan atau tanpa pesanan. Namun menurut narasumber bahwa dari BRISyariah dalam pembiayaan KPR hanya dilakukan dengan pesanan. Pada saat akad murabahah disetujui, piutang murabahah diakui sebesar biaya perolehan aset murabahah ditambah keuntungan yang disepakati. Diskon dapat diberikan sesuai ketentuan yang berlaku namun tidak dapat diperjanjikan diawal. Diskon pembelian aset murabahah diakui sebagai pengurang biaya perolehan aset murabahah jika terjadi sebelum akad dan kewajiban kepada pembeli , jika terjadi setelah akad. Pada saat akad murabahah, piutang diakui sebesar biaya peroleha aset murabahah ditambah keuntungan yang disepakati., piutang murabahah disajikan sebesar nilai bersih yang dapat direalisasi, yakni saldo piutang dikurangi dengan cadangan kerugian penurunan nilai. Pelunasan dipercepat atau pelunasan sebelum jatuh tempo untuk piutang murabahah diperlakukan sebagaimana pelunasan piutang sesuai dengan masa jatuh temponya (biasa).

Denda dikenakan jika pembeli lalai dalam melakukan kewajibannya sesuai dengan akad, dan denda yang diterima diakui sebagai dana kebajikan, Pengakuan dan pengukuran akad murabahah di BRI Syariah Cabang Jombang dapat dijelaskan melalui ilustrasi kasus. ilustrasi kasus berikut adalah salah satu transaksi pembelian rumah melalui produk BRISyariah yaitu menggunakan KPR BRI Syariah iB:

Pembiayaan akad murabahah dan implementasi akuntansi sesuai PSAK 102 tentang akuntansi murabahah (jual-beli) oleh nasabah Bapak Aksono di Bank BRISyariah Cabang Jombang diman : 
Tabel 1. Ilustrasi Akad Murabahah

\begin{tabular}{ll}
\hline Tujuan penggunaan & $:$ Pembelian satu unit rumah baru dengan KPR \\
& BRI Syariah iB \\
\hline Harga rumah & $:$ Rp. $300.000 .000,-$ \\
Uang Muka & $:$ Rp. $60.000 .000,-$ \\
Tingkat margin flat & $: 14 \%$ pertahun \\
Jangka waktu & $: 120$ bulan atau 10 tahun angsuran pelunasan \\
\hline
\end{tabular}

Bank melakukan kesepakatan dengan mengambil margin keuntungan 14\% / tahun.

Maka penyelesaiannya sebagai berikut :

- $\quad$ Harga rumah $=$ Rp. 300.000.000,

- $\quad$ Uang muka $=($ Rp. $60.000 .000,-)$

- $\quad$ Nilai KPR $=$ Rp. 576.000.000,

- $\quad$ Margin $=14 \%$ x 10thn x Rp. $240.000 .000=$ Rp. 336.000.000,-

Jadi, diperoleh margin sebesar Rp. 336.000.000,- selama 10 tahun.

- $\quad$ Margin per bulan = Rp. 336.000.000,- /120 = Rp. 2.800.000,-

- Angsuran per tahun=(Pokok x margin $x$ jangka waktu) / Jangka waktu + pokok

$$
\begin{aligned}
& =(\text { Rp. } 240.000 .000 \times 14 \% \times 120)+\text { Rp. } 240.000 .000 \\
& =\text { Rp. } 57.600 .000
\end{aligned}
$$

Jadi, diperoleh angsuran per tahun sebesar Rp. 57.600.000,-.

$$
57.600 .000,-. / 12=\text { Rp. } 4.800 .000,-
$$$$
\text { Angsuran per bulan }=\mathrm{Rp} \text {. }
$$

Jadi, diperoleh angsuran per bulan sebesar Rp.4.800.000,-. Maka BRISyariah Cabang Jombang. menjurnal sebagai berikut :

- Saat realisasi pembiayaan

Aktiva murabahah Rp.240.000.000,

Utang pembelian murabahah Rp.240.000.000,-

\section{- Saat penjualan rumah}

Piutang murabahah Rp.240.000.000,-

Aktiva murabahah Rp.240.000.000,-

- Saat menerima pendapatan administrasi

Kas Rp. 2.400.000,

Pendapatan administrasi Rp.2.400.000,-

- Saat pembayaran bank kepada developer

Utang pembelian rumah Rp.300.000.000,-

Kas Rp.300.000.000,-

- Saat menerima angsuran dari Dewantara

Tabungan DewantaraRp. 4.800.000,-

Piutang murabahah Rp. 4.800.000,-

\section{- Saat pengakuan pendapatan}

Pendapatan diterima dimuka Rp. 2.800.000,-

Pendapatan margin

Rp. 2.800.000,-

Bank BRISyariah membeli sendiri barang yang dipesan oleh nasabah dengan harga perolehan sebesar Rp. 300.000.000,- atas pembelian tersebut nasabah menyerahkan uang muka kepada bank sebesar Rp. 60.000.000 maka pembiayaan bank sebesar Rp. 240.000.000 (harga beli-uang muka). Maka pencatatan transaksi piutang murabahah sebagai berikut: 
a. Pada saat perolehan asset murabahah

BRISyariah mencatat asset murabahah yang diperoleh sebagai persediaan sebesar biaya perolehan pada saat perolehan, karena asset tersebut diperoleh dengan tujuan untuk dijual kembali. Kemudian asset tersebut akan dijual kepada nasabah sebagai pembeli sebesar harga yang disepakati kedua belah pihak yaitu, harga beli ditambah dengan margin keuntungan. Pencatatan perolehan asset murabahah adalah sebagai berikut:

Persediaan Rp 300.000.000

Kas/rekening developer $\quad \mathrm{Rp} 300.000 .000$

Menurut PSAK No.102, pada saat perolehan aset murabahah diakui sebagai persediaan sebesar biaya perolehan. Jurnal atas perolehan aset, yaitu:

Db. Aset/Persediaan Murabahah xxx

Kr. Kas/Rekening Supplier $\quad \mathrm{xxx}$

Hasil Analisis :

Bank BRISyariah mengakui aset yang diperoleh sebagai persediaan sebesar biaya perolehan yaitu sebesar Rp 300.000.000,- maka pencatatan tersebut telah sesuai dengan PSAK No.102 (paragraf 18).

b. Pada saat perjanjian Murabahah

Bank menetapkan harga jual Rp 576.000.000,- ada selisih harga yang merupakan margin bagi pihak bank sebesar Rp 276.000.000,-. Jangka waktu murabahah 120 bulan dengan biaya administrasi $\mathrm{Rp} 2.000 .000$,- dan jika terjadi keterlambatan pembayaran angsuran akan dikenakan denda Rp 100.000,-

\section{Pengungkapan}

Penjual mengungkapkan hal-hal yang terkait dengan transaksi murabahah, tetapi tidak terbatas pada :

a. harga perolehan aset murabahah ;

\section{Saat menerima angsuran dari Dewantara}

Tabungan DewantaraRp. 4.800.000,Piutang murabahah Rp. 4.800.000,-

\section{Saat pengakuan pendapatan}

Pendapatan diterima dimuka Rp. 2.800.000,-

Pendapatan margin Rp. 2.800.000,-

Penyajian dalam kaitannya dengan piutang murabahah oleh Bank BRISyariah disajikan di neraca pada sisi asset sebesar tagihan bank kepada nasabah sedangkan untuk komponen laba/rugi disajikan dalam bentuk pengelompokkan pendapatan dan beban menurut karakteristik transaksi. Rekening nasabah disajikan dalam neraca dibagian pasiva, rekening ini terpengaruh karena dalam praktik bank BRISyariah Cabang Jombang, penerimaan angsuran oleh bank dilakukan dengan mendebet berupa rekening giro maupun tabungan, sesuai untuk mendebet secara otomatis setiap bulan oleh bank BRISyariah.

b. Janji pemesanan dalam murabahah berdasarkan pesanan sebagai kewajiban. Bank BRISyariah dalam menjalankan akad murabahah pada KPR hanya berdasarkan pemesanan, jadi bank akan merealisasikan KPR sesuai dengan pesanan nasabah.

c. pengungkapan yang diperlukan sesuai PSAK No. 101 tentang Penyajian Laporan Keuangan Syariah.

Hasil Analisis :

Dalam Pengungkapan tentang penyajian di Bank BRISyariah Cabang Jombang telah sesuai dengan PSAK 101 dimana Laporan keuangan menyajikan secara 
wajar posisi keuangan, yang sesuai dengan Pernyataan Standar Akuntansi Keuangan dalam Catatan atas Laporan Keuangan. Informasi lain tetap diungkapkan untuk menghasilkan penyajian yang wajar walaupun pengungkapkan tersebut tidak diharuskan oleh Pernyataan Standar Akuntansi Keuangan.

\section{E. PENUTUP}

Setelah dianalisa maka penulis dapat menarik kesimpulan, Dalam Penerapan Akuntansi Murabahah dalam Pembiayaan Kredit Kepemilikan Rumah (KPR) bedasarkan PSAK 102 di BRISyariah Cabang Jombang, Bahwa :

1. Bank BRISyariah Cabang Jombang telah menerapkan pembiayaan yang operasionalnya sesuai dengan ketentuan yang berlaku yaitu Pernyataan Standar Akuntansi Keuangan (PSAK) Nomor 102 tentang Akuntansi Murabahah. Di dalam pelaksanaan pembiayaan murabahah, Bank BRISyariah Cabang Jombang bertindak sebagai penjual dan nasabah sebagai pembeli; Analisis $5 \mathrm{C}$ sebagai dasar pertimbangan pemberian kredit kepemilikan rumah (KPR) di Bank BRISyariah Cabang Jombang.

2. Pengakuan dan Pengukuran di BRISyariah secara umum belum sesuai dengan PSAK 102 , namun saat angsuran keterlambatan atau denda BRISyariah cabang jombang dalam jurnalnya tidak sesui dengan PSAK 102 karena Bank BRISyariah mengakui denda sebagai pendapatan. Dalam Penyajian Dalam Penyajian Piutang murabahah BRISyariah sudah sesuai dengan PSAK 102 dimana pada saat proses penjurnalan disajikan sebesar nilai bersih yang dapat direalisasikan, yaitu saldo piutang murabahah dikurangi penyisihan kerugian piutang. Keuntungan murabahah tangguhan disajikan sebagai pengurang piutang murabahah. Pengungkapan piutang murabahah di BRISyariah Cabang Jombang disajikan di neraca pada sisi asset sebesar tagihan bank kepada nasabah. Hal tersebut diatas telah sesuai dengan PSAK No 102.

3. Saran Bagi BRI Syariah Cabang Jombang, Bank BRISyariah Cabang Jombang dalam oprasional pembiayaan murabahah pada Kredit Kepemilikan Rumah lebih memaksimalkan promosi tentang produk KPR sesuai yang diharapkan dengan nasabah, Bank BRISyariah dalam Pengungkapan dan Pengukuran khususnya perihal dana denda seharusnya disesuaikan dengan PSAK 102 Revisi 2013 yang dimana dana denda seharusnya masuk ke rekening Kebijakan Sosial atau lembaga zakat.

\section{DAFTAR PUSTAKA}

Anisah, N., \& Utomo, L. P. (2017). Persepsi Akuntan Tentang Penerapan Prinsip-Prinsip Akuntansi Syariah Dalam Lembaga Keuangan Syariah. Assets: Jurnal Akuntansi dan Pendidikan, 6(2), 107-116.

Alfiatus Sa'adah Isna, 2015 Mekanisme Dan Upaya Peningkatan Tabungan Faedah di brisyariah kantor cabang pembantu sunan kalijogo-demak. Program Studi (D3) Perbankan Syariah fakultas ekonomi dan bisnis islam uin walisongo

Masyhuri, M. Zainuddin. 2008. Metodologi Penelitian Pendekatan Praktis dan Aplikatif, Bandung: PT. Refika Aditama.

Muhammad, 2005, Manajemen Bank Syariah, Yogyakarta : UPP AMP YKPN. 
Moleong, Lexy J. ,2007. Metodologi Penelitian Kualitatif, Bandung. Penerbit PT Remaja Rosdakarya Offset

Nur hayati, wasilah. 2014, Akuntansi Syariah di Indonesia. Jakarta: Salemba Empat.

Novan Bastian Dwi Ardha, 2011 Analisis Perlakuan Akuntansi Murabahah Pada Pt Bank Rakyat Indonesia Syariah Cabang Kota Malang. Jurusan Akuntansi Fakultas Ekonomi dan Bisnis Universitas Brawijaya.

Purbowati, R., \& Mutiarni, R. (2017). Pengungkapan Corporate Social Responsibility Ditinjau Dari Karakteristik Perusahaan. Jurnal Akuntansi Dan Bisnis: Jurnal Program Studi Akuntansi, 3(2).

Sayyid Sabiq, 2006, Fiqih Sunnah Jilid 4, terjemahanNorHasanuddin, Lc, MA dkk., Jakarta: Pena PundiAksara, hal. 145.

Siswadi Sululing, 2014. Penerapan Akuntansi Murabahah Terhadap Pembiayaan Kredit Kepemilikan Rumah (KPR) Pada Bank Mandiri Syariah Cabang Luwuk. Fakultas Ekonomi Universitas Muhammadiyah Luwuk

Sulistyo Basuki, 2006. Metode Penelitian. Jakarta: Wedatama Widya Sastra dan Fakultas Ilmu Pengetahuan Budaya Universitas Indonesia

Sugiawati, 2009. Analisis Kredit Kepemilikan Rumah (KPR) Dengan Akad Pembiayaan Murabahah di BNI Syariah Cabang Medan. Skripsi. Sumatra Utara: Prodi Akuntansi Fakultas Ekonomi Universitas Sumatra Utara.

Ulya Khalid, 2014. Evaluasi Transaksi Murabahah Berdasarkan Fikih Muamalah Dan Psak 102 (Akuntansi Murabahah) Studi Kasus PT Bank Pembiayaan Rakyat Syariah Harta Insan Karimah Cabang Ciledug. Skripsi Yogyakarta: Fakultas Ekonomi dan Bisnis Universitas Gadjah Mada.

Peraturan Bank Indonesia Nomor: 9/19/PBI/2007 tentang Pelaksanaan Prinsip Syariah dalam Kegiatan Penghimpunan Dana dan Penyaluran Dana serta Pelayanan Jasa Bank Syariah, Ditetapkan pada tanggal 17 Desember 2007

Undang-undang Nomor 21 Tahun 2008 tentang Perbankan Syariah 